\title{
医薬品開発の立場から
}

\section{From the View Point of Drug Development}

\author{
樋口 三朗 \\ （山之内製薬株式会社 代謝研究所）
}

Saburo HiguchI

Drug Metabolism Laboratories, Yamanouchi Pharmaceutical Co., Ltd, Tokyo

\section{はじめに}

臨床試験開始に必要な薬物動態試験の実施タイミング は, 製薬企業の薬物動態研究者にとって極めて重要なこ とであるが，これまでタイミングに関するガイドライン はなく，各企業の方針で実施されてきている. 1995 年 に実施された製薬協のアンケート調査によると，我国に おいては欧米の企業に比べて phase I 試験開始までにか なり多くの前臨床薬物動態試験が実施されている11)。 のような状況の中で ICH ガイドライン(M3)が公布され, phase I 試験開始は TKのみで可能であり，通常の ADME 試験は phase I 試験終了時までにヒトと動物と の比較のために実施すればよいことになっている2)。我 国において，このガイドラインの公布により，現況がど のようにハーモナイズされていくかが注目されるところ である．一方，phase I 試験開始までに実施する前臨床 試験として，従来行われてきた日本の薬物動態ガイドラ インをふまえた試験に加えて開発化合物選択に至るまで に実施される研究を考慮することが重要であると考えら れる. Discovery stage の研究成果により体内動態に優 れた化合物が選択された時, 開発のリスクは軽減され， 開発期間は短縮される. 結果として無駄な臨床試験を回 避することになり，倫理的観点からも極めて重要な意味 を持つことになる．本稿では製薬企業の立場から ICH ガイドラインについてふれ, development stage のみな らず discovery stage の研究の意義についても言及する.

\section{ICH ガイドラインについて}

臨床試験に伴って実施される前臨床試験の実施タイミ ングについて記載されているのは ICH ガイドライン E8 ${ }^{3)}$ と M3 であるが，薬物動態に言及している部分は少 なく，またその内容も吸収，分布，代謝，排泄といった もので具体的な記載は一切なされていない，E8におけ る薬物動態関連の要点は次のと抢りである．まず，被験 者の保護の項で前臨床試験の重要性が述ぺられている.
すなわち，いかなる臨床試験も，その開始にあたっては 非臨床試験または先行する臨床試験の結果から，予定さ れている臨床試験においてその治験薬が十分安全である ことが示されていなければならない。そして非臨床試験 の目的とその実施時期については M3 ガイドライン参 照となっている. 次に開発の方法の項でヒトでの最初の 投与量は臨床試験への移行前に実施される非臨床試験で の薬物動態, 薬理学的および毒性学的評価を注意深く考 察した上で決定されなければならないとした上で M3 ガイドライン参照となっている.さらに，初期段階での 臨床開発の根拠と方向性は非臨床試験での薬物動態学的 プロファイルに基づいて決定されるとし，吸収，分布， 代謝, 排泄が内容として記載されている．臨床の各相の 試験開始に必要な前臨床薬物動態試験についても具体的 な記載はまったくなされていない。一方，臨床試験にお けるヒトでの薬物動態試験については詳細な記載がなさ れており，重要視されていることが同える. Phase I 試 験についての項で, 薬物の吸収, 分布, 代謝, 排泄に関 する特徵の検出は開発計画全体を通して行われるとした 上で，これらの特徵を予備的に見いだすことは phase I 相において実施される試験の重要な目的の一つである. 薬物動態は独立した試験において評価されることもあれ ば有効性, 安全性, 忍容性の一部において評価されるこ ともある．薬物動態試験では薬物のクリアランスを評価 し，未変化体むたは代謝物の蓄積性の可能性および薬物 相互作用の可能性を予期することが重要である。 また, より特殊な問題に答えるために食事の影響, 代謝, 排泄 障害(腎, 肝疾患), 高齢者, 小览, 女性および人種差に ついても考慮しなければならない，代謝と相互作用の検 討は動物および in vitroの結果によっては早期に実施し なければならない, なた, 特別に考慮する点の項におい て, 活性代謝物を同定しその詳細な薬物動態試験を実施 しなければならない，開発計画の中で代謝に関する評価 試験を行う時期はそれぞれの薬物の性質によって決まる としている. 次に, 臨床試験開始までの前臨床薬物動態 
試験のタイミングが記載されているのが M 3 であるが, その内容は下記のごとく極めて簡潔なものである.

\section{トキシコキネティックスおよび薬物動態試験}

動物の暴露データーの評価は, ヒト臨床試験の前に行 われるべきである.さらに, 動物の吸収, 分布, 代謝, 排泄についての情報を入手して, ヒトと動物の代謝を比 較できるようにしておくべきである. 通常, phase I 試 験(ヒ卜薬理試験)の完了屯でに適切な情報を入手してお くべきである.

このガイドラインが公布された現在, 我国における薬 物動態試験ガイドラインに従った詳細な試験をいつ実施 するかは, 薬物動態研究者にとって大きな課題となって いる.

\section{Discovery stage における薬物動態研究}

最近の薬物動態研究の進歩は著しく, 医薬品の開発研 究に大きく寄与し始めている. 特に discovery stage に 関しては国際会議やワークショップでしばしば取り上げ られている4,5)。この背景にはコンビナトリアルケミス トリーによって大量の化合物が合成され，ヒット化合 物, リード化合物, 最適化合物の評価および選択に時間 と手間のかかる薬理試験の前に薬物動態スクリーニング を取り入れることが試みられていることがあげられる (図 1 ). 薬物動態スクリーニングが有用と考えられるよ うになった理由は, in vitro 研究によりヒト体内動態が ある程度予測可能になったことと, LC-MS に代表され る分析機器の進歩により, 体内動態の研究が discovery stage の研究速度についていけるようになったことがあ げられる．画期的新薬の創製が一層難しくなってきた今 日, 研究開発期間の長期化に伴うコストの増大は開発そ のもを不可能にしかねない状況にある. Phase I 試験が 実施された化合物の $50 \%$ がドロップアウトし，その $30 \%$ が薬物動態的な原因である6)ことを考慮すると， 初期のスクリーニングの段階でヒトで良好な薬物動態プ ロファイルを示す(と予測される)化合物を選択すること

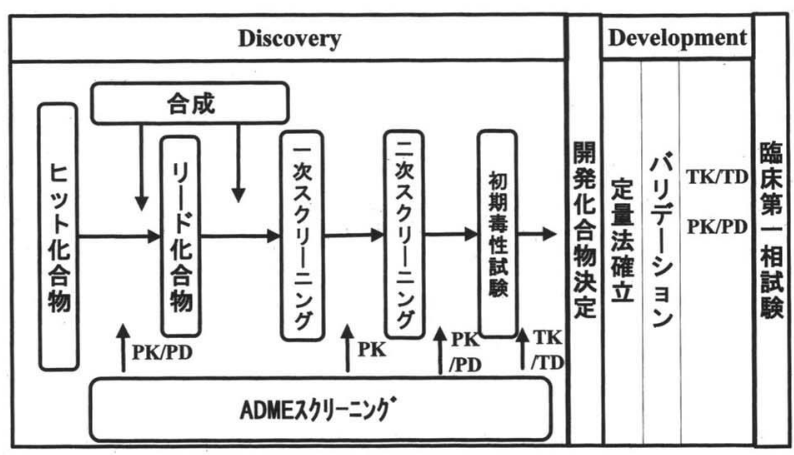

図 1 医薬品開発における薬物動態研究 (phase I 試験開始ま で)
表 1 Discovery stage における薬物動態研究の意義

薬物動態に優れた化合物を選択することによって

・優れた薬剤を患者に提供できる

・臨床開発を円滑に進めることができる

開発のスピードアップと開発コストの低減

・開発段階でのドロップアウトの回避

無駄な臨床試験を避けることができる

・この段階で薬物動態プロファイルの大要を把握でき, ヒト

への外挿もある程度は可能

表 2 開発段階で致命的なたは重大な影響をおよぼす性質 の早期発見のために必須と考えられる試験

・バイオアベラビリティおよび半隇期

・薬物代謝酵素系への影響

阻害, 誘導

- 活性代謝物の有無

・ヒト薬物動態の予測

アニマル スケールアップ

In vitro-in vivo スケーリング

がどれほど重要かは疑う余地がない。体内動態に優れた 化合物が選択されれば医療の場に優れた薬剤を提供でき る. なた, 開発は容易になり, 無駄な臨床試験を行わな くても済むようになる.ささら, 薬物動態的問題をかか えた化合物でも，臨床入り価值が十分あると判断された 化合物についてこの stage の研究が十分になされていれ ば，適切な対応が可能となる場合もありうる(表 1 )。し たがって臨床試験開始に必要な前臨床試験を考えた時, ガイドラインにそった薬物動態試験のみでなくこの stage の研究が極めて重要である. Discovery stage の 薬物動態研究法については堀江 ${ }^{6)}$ や Caldwel ${ }^{7}$ )らにより 考え方が詳細に紹介されている.ここでは深刻な開発り スクを回避するために必要な試験項目だけをとりあげる (表 2 ).

\section{1. バイオアベラビリティおよび半減期}

研究初期段階では合成された化合物の量が限られてい るので通常はラット等の小動物を使用することになる. バイオアベラビリティは静脈内投与および経口投与時の AUC から算出されているが, この値が極めて小さい時 (10\%以下)にはその要因を考えなければならない。薬 物の溶解性, 消化管での安定性, 吸収, 消化管壁での代 謝, 肝臟での代謝等である. 原因が消化管の管腔内にあ る場合には製剤工夫によりバイオアベラビリティ向上の 検討が必要になる。代謝が原因の場合は in vitro におけ る代謝の検討が重要になる。 また, 動物で半減期が極端 に短く代謝が関与している場合には, スケーリングによ りヒトでの半減期の推定が極めて有用となる. 図 2 に当 社で最近経験した例を示す。化合物 $\mathrm{A}$ はラット, イヌ 


\section{化合物 $A$}

\begin{tabular}{|l|c|c|}
\hline & 半減期 $(\mathrm{h})$ & パイオアベイラビリティ (\%) \\
\hline ラット & $1.4 \sim 3.1$ & $0.2 \sim 1.8$ \\
\hline イヌ & $2.4 \sim 3.0$ & $3.0 \sim 25.1$ \\
\hline
\end{tabular}

\section{肝ミクロゾームにおける代謝速度}

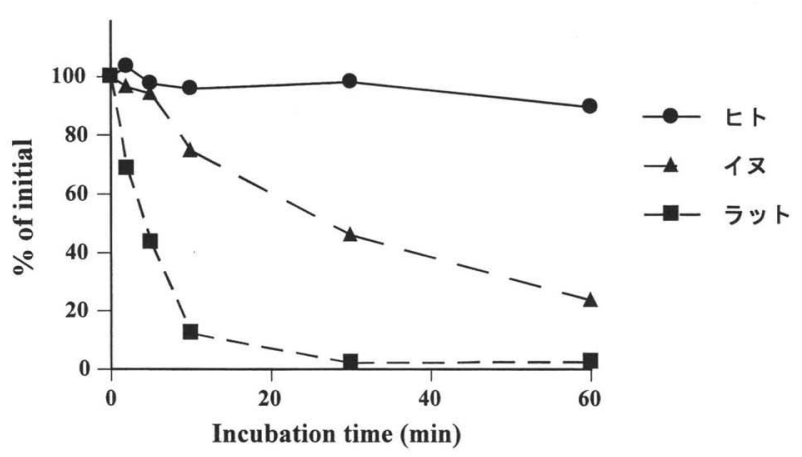

図 2 バイオアベラビリティおよび半減期の評価の実例

において半減期は短く，バイオアベラビリティも極めて 小さい. しかし，この化合物は肝ミクロゾームを用いた 試験においてラットおよびイヌに比べてヒトでは極めて 代謝がおそいことが明らかとなり，これを根拠に開発を 進めた結果, ヒトでin vivo で良好な $\mathrm{PK}$ を示す薬剤を 見いだすことに成功した。

\section{2. 薬物代謝酵素系への影響}

酵素阻害作用については発現系を用いた in vitro 試験 で容易に検出できることから早期に検討しておくことが 好ましいと考えられる8). 誘導作用が示唆された場合 (多くは予備毒性試験の自己誘導でみいだされる)には種 差の有無と投与量依存性の検討を行い, ヒト臨床用量で の可能性を推測する(極めて難しいが)，表 3 にその例を 示す．化合物 $\mathrm{B}$ はラット，イヌで顥著な酵素誘導作用 を示したがサルでは示さなかった．さらに代謝の速度， パターンはサルとヒトは近似していたことからヒトでは 酵素誘導作用を示さないことが期待される. また化合物

表 3 酵素誘導作用の実例

$\begin{array}{ll}\text { 化合物 B } & \\ \text { ラット, イヌ } & \text { 自己誘䆃作用あり } \\ \text { サル } & \text { 酵素にも影響あり) } \\ \text { In vitro 試験 } & \text { 自己誘導作用なし } \\ \text { ラット, イヌ } & \\ \text { サル, ヒト } & \text { 代謝されやすい } \\ \text { 化合物 C } & \text { ほとんど代謝されない } \\ \text { ラット, イヌ } & \\ & \text { 自己誘導作用(高用量) } \\ & \text { 低用量ではみられない }\end{array}$

Cの場合にはラット，イヌの高用量で誘導作用がみられ たが低用量ではみられないことから，ヒト臨床用量で誘 導作用を示さないことが期待されている. しかし, 動物 の結果からヒトの予測を行うことは極雉しく, 我国 においてもヒト肝へパトサイト等を用いた試験が評価系 として用いることが切望される.

\section{3. 活性代謝物}

未変化体の測定で PK/PDの説明がつかないときは活 性代謝物の存在が考えられるので代謝物の検索同定を行 い，合成および薬理試験が必要となる．さらにヒトを含 めた in vitro での種差の検討が必要と考えれれる. プロ ドラッグになるときは活性代謝物を開発できない理由が 必要と考えられる(表 4 ).

\section{4. ヒト体内動態の予測}

予備毒性に進むころには毒性に用いる動物種とヒトと の in vitro での代謝パターンの比較が極めて重要となる.

Phase I 試験で得られた代謝情報でヒトと動物との代謝 に顕著な差が認められた場合には，ヒトに代謝が類似し た種をスクリーニングし，毒性の再試験が必要となる. 場合によっては開発が中断することもありうる。したが って，この時期に代謝パターンを比較検討しておく意義 は大きい. 図 3 に例を示す．化合物 D はラット，イヌ ミクロゾームでほとんど代謝されず，ヒトミクロゾーム においてのみ代謝され 2 種の代謝物を生成した。 そこ で 7 種の動物をスクリーニングした結果，リスザルと マーモセットがヒトに似ていることを見いだし，マーモ セットの毒性試験を実施し phase I 試験が可能となっ た. また，化合物 Aの場合，ラットにおける代謝が速 く TKにおける暴露量に懸念があったことから，同様 にスクリーニングを実施したところマウスが最もヒトに

\section{表 4 活性代謝物検討の重要性}

・未変化体の測定で PK/PD の説明が付かないときは, 活性 代謝物の存在が考えられる

- 代謝物同定 $\rightarrow$ 合成 $\rightarrow$ 薬理作用

・ヒトを含めた種差の検討 (in vitro)

・プロドラッグになるときは, プロドラッグとしての開発理 由が必要

（活性代謝物を開発できない理由）

\section{表 5 ヒトPKの予測}

・アニマル スケールアップ

・In vitro-in vivo スケーリング

PK (動物, iv, po)

尿中排泄 (動物)

血漿蛋白結合率 (動物, ヒト) 


\section{化合物D \\ In vitro $\quad$ ラット、イヌ ほとんど代謝されない \\ 溽特有の代謝物2種生成 \\ スクリーニングリスザルとマーモセットの代謝がヒトに近いことを確認}

\section{化合物 $A$}

肝ミクロゾームにおける代謝速度

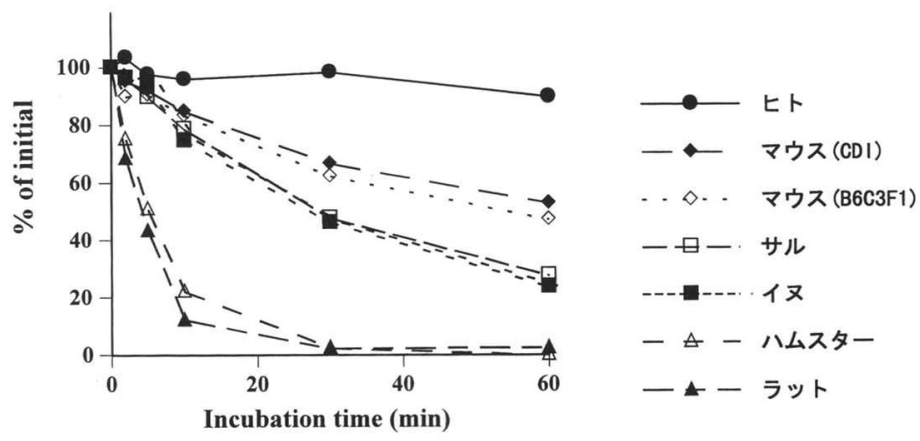

図 3 種差の検討の実例

似ていることを見いだし，マウスの毒性試験を追加し た。さらに，ヒトでの扔抢よその臨床用量の推定は phase I 試験の初回投与量決定の参考となる．この推定 は採算性(原価計算)の判断にも重要であり, 開発の可否 を決める要素ともなる.ヒトPKの予測法としてはアニ マルスケールアップや in vitro/in vivo スケーリングの 手法がある(表 5 )。 スケーリングには複数の種の in vitroの代謝速度と in vivo (静脈内, 経口)の PK および 蛋白結合率データーが必要となる9).

これまでは，ヒト体内動態はヒトに投与してみなけれ ばわからないといわれてきた。しかし，薬物動態研究者 が様々な手段を手中にした現在，体内動態に問題を抱え た化合物を選択した時の開発リスクを考えれば，化合物 の構造变換が可能な時期に体内動態研究を積極的に取り 入れていくことが薬物動態研究者に課せられた使命では ないだろうか。

\section{Development stage における薬物動態研究}

開発化合物が選択された後 phase I 試験開始に至る期 間は通常安全性研究が律速になる場合が多い。この間に 実施しなければならない薬物動態関連試験としては, TK および phase I 試験に用いる定量法の開発, バリデ ーション, TK 測定および薬物動態ガイドラインにそっ た試験がある(表 6 ). 定量法開発，バリデーションおよ びTK 実施は必須である. 一方, 薬物動態試験に関し ては 1995 年に製薬協でアンケートが実施されたが，そ の後, M3 の内容の公表や TK の実施等の状況の変化が あったので, 今回のフォーラムを機会に同様の調査を行 い13 社(当社を含む)から回答を得た。
表 6 Development stage に抢ける薬物動態研究 (phase I 試験開始まで)

- 分析法の確立

TK 用

臨床試料測定用 (高感度)

・バリデーション試験

- TK(TK/TD)

- $\mathrm{ADME}$ 試験 $(\mathrm{PK} / \mathrm{PD})$

(M 3 では TKのみ, phase I 試験終了時までに適切な $\mathrm{ADME}$ 試験を実施)

表 7 世界最初の phase I 試験を国内で実施する会社の 70\%以上が実施している ADME 試験(1998.7現在)

・吸収 吸収率, 絶対バイオアベイラビリティ 単回投与後の血中濃度の経時推移(総放射能，未変 化体)

血中濃度の線形性を示す用量範囲 血中濃度の種差の有無と程度

TK, PK/PD

- 分布 蛋白結合率, 血球移行 単回投与後の組織内濃度の経時推移(定性的 $\mathrm{ARG}$, 定量的濃度測定)

- 代謝 In vitro 代謝の有無と程度 In vivo 主要代謝物の同定·定量 代謝経路の推定 代謝の種差の有無と程度 CYP450 の関与の有無, 主要代謝経路の推定

- 排泄 尿中排泄の速度と程度 粪中排泄の速度と程度 胆汁中排泄の速度と程度

回答 13 社の $70 \%$ (9 社) 以上が phase I 試験開始まで に実施していると回答した試験項目を表 7 に示した.今 
回の調査では 3 年前の調査結果と比較して in vitro の試 験が多く実施されるようになり, CYP450 分子種の同 定 (8 社) や薬物代謝酵素系への影響 (7 社) が検討される ようになった。 また, TK 試験が定着したことも伺え た. しかしその他の試験項目に関してはこの 3 年間で 大きな変化はなく, 各社とも phase I 試験開始まで依然 多くの試験を実施しているのが現状である. 今後, M3 の公布とともにこの現況がどのようにハーモナイズされ ていくかが大きな課題であると考えられる.

\section{ま とめ}

Discovery stage の研究を重点的に実施することによ り，体内動態的に優れた化合物を選択することができれ ば臨床試験を円滑に進めることができ，無駄な試験を回 避する可能性が大きくなる，また結果として，この段階 で薬物動態プロファイルの大要が把握でき, ある程度の ヒトへの外挿が可能なこともある. 化合物選択後の薬物 動態研究の目的が安全性試験の解釈への情報提供や臨床 における様々な変動要因を推定し, 最適の用法用量への 情報を提供することにあるとすれば, phase 2 試験開始 まではその化合物特有の体内動態研究に集中することが 必要だと考える，いずれにしても，全ての化合物を対象 に作成されている薬物動態試験ガイドラインの内容を phase I 試験までに網羅することは現実的でなく，M3
の公布に伴い柔軟性のある現実的な対応でハーモナイズ されていくことを期待したい.

謝 辞: 今回のアンケートにご協力頂きました下記 12 社に感 謝いたします、なお，アンケートの集計は当社を含む 13 社で 行いました.

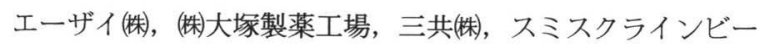

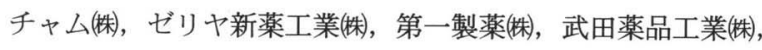
中外製薬(侏), 藤沢薬品工業(㑣), 富士レビオ(榘), ブリストルマイ

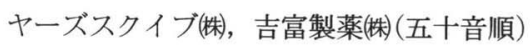

\section{文献}

1）製薬協医薬品評価基礎研究会資料 $68,1995$.

2) ICH ガイドライン M3, 1998.

3） ICH ガイドライン E8, 1998.

4）第 7 回北アメリカISSX 学会, Sandiego, 1996.

5) Novel strategies for accelerated ADME/toxicity screening for lead optimization, Philadelphia, 1997.

6) 堀江 透: 薬物動態, 12(2): 152, 1997.

7) Caldwel J : 薬物動態, 11(1): 119, 1996.

8) Crespi C. L. and Miller V. P.: Microtiter plate assays for inhibition of human, drug-metabolizing cytochrome P450. Anal. Biochem. 248: 188, 1997.

9）杉山雄一(編): 医薬品開発における薬物動態研究, 薬業時 報社, 1998 . 